Ляхович О. О. ${ }^{[1 ; 0 R C I D ~ I D: ~ 0000-0002-6770-7970], ~}$ к.е.н., доцент

${ }^{1}$ Національний університет водного господарства та природокористування, м. Рівне

\title{
ОСОБЛИВОСТІ ЗАСТОСУВАННЯ МЕТОДІВ НАУКОВИХ ДОСЛІДЖЕНЬ У ФІНАНСОВО-ЕКОНОМІЧНІЙ СФЕРІ
}

у статті досліджено теоретичні засади застосування методів наукових досліджень у фінансово-економічній сфері. Розглянуто структуру методики фінансово-економічних досліджень та застосування загальнонаукових та конкретно-наукових методів. Визначено особливості застосування методів в основній частині дослідження.

Ключові слова: методи; методика; наукове дослідження; фінансовоекономічна сфера.

Вступ. Обґрунтованість та правильність вибору методів наукового дослідження відіграють важливу роль на всіх етапах його проведення. Адже застосування правильних методів спрямовує хід думок дослідника на вирішення поставлених проблем, відкриває перед ним найкоротший шлях для досягнення мети і забезпечує раціональне використання ресурсів під час дослідження. Оскільки фінансово-економічні дослідження характеризуються специфічними підходами до їх організації, то визначення особливостей застосування методів у цій сфері складає актуальність даної тематики. Саме тому кожний метод наукового пізнання у фінансовоекономічній сфері слід розглядати як систему регулятивних принципів практичної і теоретичної діяльності людини.

Аналіз останніх джерел і публікацій. Питання застосування методів наукових досліджень та критеріїв їх вибору досить детально досліджено у працях таких вітчизняних фахівців як О.І. Гуторов, В.І. Зацерковний, І. В. Тішаєв, В.К. Демидов, А. Є. Конверський, А. О. Афанасьєв, Є. В. Кузькін, А. Я. Баскаков, Н.В. Туленков, М. Т. Білуха, Г. О. Бірта, Ю.Г. Бургу, А. В. Демківський, П. І. Безус, М.С.Дороніна та ін. Проте теоретико-практичні аспекти особливостей застосування наукових методів у фінансовоекономічних дослідженнях потребують більш детальнішого висвітлення та обґрунтування. 
Метою статті $\epsilon$ дослідження сутності та особливостей загальнонаукових та конкретно-наукових методів наукових досліджень у фінансово-економічній сфері.

Основна частина. Методика досліджень теми - це конкретизація прийомів і способів виконання робіт відповідно до мети та плану дослідження. Структура методики включає загальні положення, основну частину і висновок. У кожному підрозділі методики дослідження потрібно передбачати загальнонаукові і конкретно-наукові методи дослідження, які застосовуватимуться в процесі виконання наукової роботи за певною темою. При цьому один методичний прийом може доповнюватися іншим. Розглянемо більш детально структуру методики фінансово-економічних досліджень та застосування відповідних методів.

У загальних положеннях фінансово-економічних досліджень вказується мета обраної теми, основна гіпотеза, здійснюється обґрунтування іï для проведення дослідження, визначаються розділи та етапи дослідження теми та їх виконавці. Також визначається галузь, на матеріалах якої провадиться дослідження, базове підприємство, корпорація, об'єднання, передбачається форма і місце впровадження результатів дослідження, вибираються основні показники техніко-економічного обґрунтування дослідження.

Основна частина наукового фінансово-економічного дослідження містить деталізований виклад методичних вказівок щодо організації і проведення дослідження теми. У ній визначаються об'єкти і методи дослідження, джерела інформації, узагальнення і реалізація результатів дослідження. Таким чином, структура методики розробляється у повній відповідності з моделлю тематики наукового дослідження з конкретної фінансово-економічної ситуації [2].

На першому етапі досліджень у фінансово-економічній сфері використовують індуктивний метод, яким передбачається збирання, систематизація й узагальнення фактів, причетних до проблеми, яка вимагає вирішення. При цьому не можна користуватися випадковими, сумнівними, поодинокими фактами. Адже неможливо зробити узагальнення, сформулювати економічні принципи, вивчити закономірності, не спираючись при цьому на масові типові і достовірні факти (явища), тобто на практику. Лише вона виступає критерієм істини, правильності й обгрунтованості фінансовоекономічної політики. Завершальною стадією індуктивного методу, якій передують збирання і систематизація фактів (явищ), $\epsilon$ виведення 3 них фінансово-економічних принципів, теорій, 
узагальнень. Як бачимо, індукція йде від окремого (часткового) до загального, в результаті чого викристалізовується все спільне, що характерне для даних фактів (явищ), їх економічна поведінка, закономірності розвитку.

Також, у фінансово-економічних дослідженнях, крім індуктивного, часто застосовують дедуктивний метод (рисунок), коли вирішення проблеми починають не зі збирання фактів, а 3 теоретичного, абстрактного осмислення ії, спираючись при цьому на логіку мислення, випадкові спостереження, інтуїцію. В результаті формулюється гіпотеза, що надає дослідницькій роботі цілеспрямованості і логіки здійснення через пошук, вивчення та систематизацію фактів, які підтверджують, чи навпаки, спростовують iï. У процесі такого пошуку висунуті гіпотези уточняються і за умови підтвердження їх ідей фактами, практикою стають фінансовоекономічними теоріями, які виявляють загальні принципи економічної поведінки [1].



Рисунок. Використання індуктивного та дедуктивного методів у наукових дослідженнях [1]

Окрім використання індуктивного та дедуктивного методів, у наукових дослідженнях застосовують такі загальнонаукові методи, 
як аналіз і синтез, аналогія і моделювання, абстрагування і конкретизація, системний аналіз, а також конкретно-наукові методичні прийоми, зокрема органолептичні, розрахунковоаналітичні, документалістики.

Органолептичні (від грец. - знаряддя, інструмент) - методичні прийоми дотикового характеру, коли дослідження провадяться способом безпосереднього дотику до об'єктів спостереження. До них належать інвентаризація, контрольні заміри, вибіркові та суцільні спостереження, технологічні та хіміко-технологічні дослідження, експертизи.

Розрахунково-аналітичні - функціонально-вартісний аналіз, економічний аналіз, статистичні розрахунки, економіко-математичні методи. Функціонально-вартісний аналіз - метод дослідження об'єкта (виробу, процесу, структури) за його функцією і вартістю, який застосовується при вивченні ефективності використання матеріальних і трудових ресурсів. Найважливішими його функціями $€$ :

- функціональний підхід при дослідженні функцій об'єкта та його елементів з метою найповнішого задоволення вимог у виборі раціональних шляхів їх реалізації;

- оцінка споживчих якостей і витрат на їх розробку, виробництво і використання об'єкта;

- відповідність корисності функцій витратам на їх здійснення;

- колективна творчість, яка використовує методи пошуку і формування технічних рішень, якісної і кількісної оцінок варіантів рішень.

Економічний аналіз - система прийомів дослідження для розкриття причинних зв'язків, що зумовлюють результати явищ i процесів. Застосовується економічний аналіз у всіх видах досліджень виробничої і фінансово-господарської діяльності об'єднань, корпорацій.

Статистичні розрахунки - прийоми одержання таких величин і якісних характеристик, яких немає безпосередньо в економічній інформації підприємства, що досліджується. Застосовуються вони при потребі відтворення реальних кількісних відношень, виправлення приблизних величин або переходу від одних величин до найбільш точних характеристик якісних зв'язків і відношень. За допомогою статистичних розрахунків визначають коефіцієнти фінансово-економічного стану об'єкта дослідження.

Економіко-математичні методи застосовуються у наукових дослідженнях при визначенні впливу факторів на результати 
господарських процесів з метою оптимізації їх на стадії планування і проєктування, а також після завершення господарських процесів, якщо іншими методичними прийомами встановити взаємозв'язки факторів неможливо, наприклад, оптимізація використання фінансових ресурсів, кореляційний аналіз основних технікоекономічних показників та ін. [3].

Документалістика включає інформаційне моделювання, дослідження документів, нормативно-правове регулювання та ін. Так, інформаційне моделювання - це інформаційна сукупність, що подає досліджуваний об'єкт у вигляді моделі. При формуванні інформаційної моделі необхідно забезпечити повноту характеристики об'єкта дослідження. При моделюванні використовується нормативно-правова, договірна, облікова, звітна та інша інформація про об'єкти. При цьому вивчаються об'єкти основних фондів, товарно-матеріальні цінності, кошти та інші засоби, відображені в системі планової, договірної, нормативно-правової та облікової інформації.

Дослідження документів - прийоми документалістики, які застосовуються при вивченні достовірності, доцільності, ефективності господарських операцій за документами, відповідності їх законодавчим та нормативно-правовим актам, що регулюють процес виробництва. Нормативно-правове регулювання - система прийомів, що використовуються у наукових дослідженнях для виявлення нормативних і правових актів.

Аналітичне і синтетичне документування ґрунтується на індуктивних і дедуктивних загальнонаукових методичних прийомах, застосовується при дослідженні закономірностей явищ і наслідків у фінансово-господарській діяльності підприємств, банків, грошового обігу тощо [4].

Саме тому в основній частині методики досліджень за темою із загальнонаукових і конкретно-наукових методів дослідження вибирають ті, які дають змогу всебічно вивчити фінансовоекономічні процеси, визначити закономірності і тенденції їх розвитку, намітити напрями подальшого удосконалення цих процесів, виявити наявні резерви і розробити науково обґрунтовані рекомендації щодо їх використання у фінансово-економічній діяльності.

Висновок 3 проведеного дослідження. На основі проведеного дослідження можна зробити висновок, що при виборі методів дослідження у фінансово-економічній сфері доцільно надавати перевагу методам математичної статистики, функціонально- 
вартісному, системному і фінансово-економічному аналізу. Проте ці методи потребують залучення великих масивів фінансовоекономічної інформації та трудомісткої обчислювальної обробки їх. Тому аналітично-розрахункові процедури у дослідженнях необхідно виконувати 3 використанням спеціального програмного забезпечення. Для цього потрібно мати бібліотеку стандартних програм, призначених для розв'язання завдань дослідження фінансово-економічних питань. Також необхідно використовувати економічну інформатику, яка у комплексі поєднує наукові та інженерні аспекти розробки, проєктування, створення, оцінки та функціонування комп'ютеризованих систем збирання, передавання, зберігання та обробки інформації, застосування їх і вплив на достовірність результатів наукового дослідження.

1. Андрійчук В. Г. Економіка аграрних підприємств : підручник. 2-ге вид., доп. і перероблене. К. : КНЕУ, 2002. 2. Гуторов О. І. Методологія та організація наукових досліджень : навч. посіб. Харків : ХНАУ, 2017. 272 с. 3. Зацерковний В.І., Тішаєв І. В., Демидов В. К. Методологія наукових досліджень : навч. посіб. Ніжин : НДУ ім. М. Гоголя, 2017. 236 с. 4. Основи методології та організації наукових досліджень : навч. посіб. для студентів, курсантів, аспірантів і ад'юнтів / за ред. А. Є. Конверського. Київ : Центр учбової літератури, 2010. 352 с.

\section{REFERENCES:}

1. Andriichuk V. H. Ekonomika ahrarnykh pidpryiemstv : pidruchnyk. 2-he vyd., dop. i pereroblene. K. : KNEU, 2002. 2. Hutorov 0. I. Metodolohiia ta orhanizatsiia naukovykh doslidzhen : navch. posib. Kharkiv : KhNAU, 2017. 272 s. 3. Zatserkovnyi V. I., Tishaiev I. V., Demydov V. K. Metodolohiia naukovykh doslidzhen : navch. posib. Nizhyn : NDU im. M. Hoholia, 2017. 236 s. 4. Osnovy metodolohii ta orhanizatsii naukovykh doslidzhen : navch. posib. dlia studentiv, kursantiv, aspirantiv i adiuntiv / za red. A. Ye. Konverskoho. Kyiv : Tsentr uchbovoi literatury, 2010. $352 \mathrm{~s}$.

Liakhovych O. O. [1; ORCID ID: 0000-0002-6770-7970], Candidate of Economics (Ph.D.), Associate Professor

${ }^{1}$ National University of Water and Enviromental Engineering, Rivne

\section{APPLICATION PECULIARITIES OF SCIENTIFIC RESEARCH METHODS IN THE FINANCIAL AND ECONOMIC SPHERE}

The article investigates the theoretical foundations of the application of research methods in the financial and economic sphere. The structure of the methodology of financial and economic research and the application of general scientific and specific scientific methods are considered. 
Peculiarities of application of methods in the main part of the research are determined.

The article also describes the inductive method, which provides for the collection, systematization and generalization of facts relevant to the problem that requires solution. It is determined that the final stage of the inductive method, which is preceded by the collection and systematization of facts (phenomena), is the derivation of financial and economic principles, theories, generalizations. Also it is established that as a result of application of a deduction method the hypothesis giving to research work purposefulness and logic of realization through search, studying and systematization of the facts which confirm, or on the contrary, refute it is formulated.

The article states that in addition to the use of inductive and deductive methods in scientific research, such general scientific methods as analysis and synthesis, analogy and modeling, abstraction and concretization, system analysis, functional-cost analysis and specific scientific methods are used: organoleptic, computational -analytical, documentary.

The conclusions of the article indicate that in the main part of the research methodology on the topic of general and specific scientific research methods choose those that allow a comprehensive study of financial and economic processes, identify patterns and trends in their development, identify areas for further improvement of these processes. reserves and develop scientifically sound recommendations for their use in financial and economic activities.

Keywords: methods; methods; scientific research; financial and economic sphere.

Ляхович О. А. ${ }^{[1 ; 0 R C I D ~ I D: 0000-0002-6770-7970], ~}$ к.э.н., доцент

${ }^{1}$ Национальный университет водного хозяйства и природопользования, г. Ровно

\section{ОСОБЕННОСТИ ПРИМЕНЕНИЯ МЕТОДОВ НАУЧНЫХ ИССЛЕДОВАНИЙ В ФИНАНСОВО-ЭКОНОМИЧЕСКОЙ СФЕРЕ}

В статье исследованы теоретические основы применения методов научных исследований в финансово-экономической сфере. Рассмотрена структура методики финансово-экономических исследований и применения общенаучных и конкретно-научных методов. Определены особенности применения методов в основной части исследования.

Ключевые слова: методы; методика; научное исследование; финансово-экономическая сфера.

Стаття надійшла до редакції 25.06.2020 р. 